\title{
Postoperative Surgical Site Bacterial Infections and Drug Susceptibility Patterns at Gondar University Teaching Hospital, Northwest Ethiopia
}

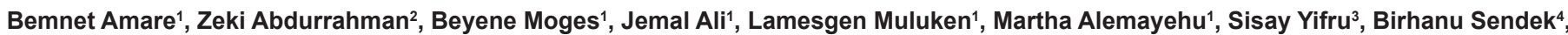
Yeshambel Belyhun $^{1 *}$, Feleke Moges ${ }^{1}$ and Afework Kassu ${ }^{1}$

${ }^{1}$ Department of Microbiology, Immunology and Parasitology, College of Medicine and Health Sciences, University of Gondar, Gondar, Ethiopia

${ }^{2}$ Department of Surgery, College of Medicine and Health Sciences, University of Gondar, Gondar, Ethiopia

${ }^{3}$ Department of Pediatrics, College of Medicine and Health Sciences, University of Gondar, Gondar, Ethiopia

${ }^{4}$ Department of Gynecology and Obstetrics, College of Medicine and Health Sciences, University of Gondar, Gondar, Ethiopia

\begin{abstract}
The study aimed to determine the prevalence, etiological agents and drug susceptibility pattern of bacterial pathogens isolated from postoperative surgical site infections and hospital environment in Gondar University Teaching Hospital. Specimens were taken from patients with post operative surgical site infections seen at wards and from hospital environment. Specimens were processed for bacteriological analysis and antibiotic susceptibility test according standard procedures. Antimicrobial susceptibility test for isolated organisms was done using disk diffusion method. Of 111 pathogenic bacteria, Escherichia coli 27 (24.3\%), Staphylococcus aureus 26 (23.4\%), Coagulase negative Staphylococci $22(19.8 \%)$ and Enterobacter spp. $11(9.9 \%)$ were dominant isolates. The prevalence of methicillin resistant S. aureus was 9 (34.6\%). Seventeen (77.3\%) and 1 (4.5\%) of coagulase negative Staphylococcus were methicillin and vancomycin resistant, respectively. Coagulase negative Staphylococcus 41 (41.8\%), S. aureus 19 $(19.4 \%)$ and $P$. aeruginosa $16(16.3 \%)$ were the major isolates from 75 sites of the hospital environment with an isolation rate of $41(54.7 \%)$. The prevalence of methicillin resistant S.aureus from the environment was $2(2.0 \%)$. High level of multi-drug resistance was observed in bacteria isolates from patients compared to the bacteria isolated from the hospital environments. This study demonstrated high level of multi-drug resistance. Thus, antibiotic sensitivity testing should be carried out for all bacterial isolates of surgical wounds before chemotherapy administered to detect drug resistant strains.
\end{abstract}

Keywords: Post operative surgical site infections; Bacteria; Antibiotic susceptibility patterns; Gondar; Ethiopia

\section{Introduction}

Surgical wound infections are those infections which are confined to the incisions and involving structures adjacent to the wounds that were exposed during operation [1]. Hospital acquired surgical site infection (SSI) is one of the major health problems throughout the world and is a serious complication affecting hospitalized patients [1-4]. Among hospital acquired infections, SSI accounts for $14-16 \%$ of the inpatient infections [2]. SSI is dangerous condition with a heavy burden on the patient has been associated with an increased morbidity, mortality and health care cost that have huge economic impact [3].

The risk of acquiring hospital infection on hospitalized patients in relation to surgery is high, since about $77 \%$ of death of patients with nosocomial infections was reported to be related with post operative infections $[3,4]$. The number of surgical patients in developing countries is also increasing but surgical care given to the patients is poor. Surgical cases are responsible for approximately $6-12 \%$ of all paediatric admissions. But due to poor surgical care, there is a significant number of death and disability associated to post operative complications [4].

Microorganisms can get access into a wound either by direct contact of air borne dispersal or by contamination [5]. Although there is no definitive evidence, direct contact and poor hand washing techniques of health care practitioners during pre and post operative phases of patient care are considered to be major factors [6]. The risk of developing a surgical wound infection is largely determined by three factors: the load, type of microbial contamination of the wound and host susceptibility [7]. Certain transient organisms such as $S$. aureus, hospital acquired methicillin resistant $S$. aureus (MRSA) and coliform occur on the skin with other commensals [8] could easily contaminate the surgical wounds from poor hygiene.
Antimicrobial resistance has been a problem in the field of surgery, as advances in control of infections have not completely eradicated this problem $[9,10]$. The widespread uses of antibiotics, together with the length of time over which they have been available have led to major problems of resistant pathogens contributing to morbidity and mortality. The antibiotics resistant pathogens are acquired either from hospital environment or from the skins of infected patients [11]. Hospital acquired infections are further complicated by an increasing prevalence of multidrug resistant organisms like MRSA, methicillin resistant coagulase negative Staphylococci (MRCoNS) and vancomycin resistant Entrococci (VRE) spp [12].

In most developing countries like Ethiopia, it is a common practice that antibiotics can be purchased without prescription. This leads to misuse of antibiotics by the public thus contributing to the emergence and spread of antimicrobial resistance [13-15]. However, studies assessing the etiological agents of surgical site infections in Ethiopia are very scarce. Thus, it is necessary to identify bacterial agents and determine their antibiotic susceptibility pattern from wounds for empirical treat-

*Corresponding author: Yeshambel Belyhun, P.O. Box 196, Department of Microbiology, Immunology and Parasitology, College of Medicine and Health Sciences, University of Gondar, Gondar, Ethiopia, Tel: + 251-912-02-91-38; Fax: +251-111-14-79; E-mail: yeshi4s@yahoo.com

Received October 05, 2011; Accepted December 16, 2011; Published Decembe 23, 2011

Citation: Amare B, Abdurrahman Z, Moges B, Ali J, Muluken L, et al. (2011) Postoperative Surgical Site Bacterial Infections and Drug Susceptibility Patterns at Gondar University Teaching Hospital, Northwest Ethiopia. J Bacteriol Parasitol 2:126. doi:10.4172/2155-9597.1000126

Copyright: ( 2011 Amare B, et al. This is an open-access article distributed under the terms of the Creative Commons Attribution License, which permits unrestricted use, distribution, and reproduction in any medium, provided the original author and source are credited. 
ment in reference to the inadequate culture and sensitively service in Ethiopia [15]. Therefore, this study was aimed to determine the distribution of bacterial pathogens isolated from post-operative wounds and their antimicrobial susceptibility patterns.

\section{Materials and Methods}

\section{Study area and study population}

A cross-sectional study was carried out between January 2010 and June 2010 at University of Gondar Teaching Hospital, Northwest Ethiopia by involving consecutive in patients with post operative surgical site infections seen at surgery, and gynaecology and obstetrics wards. The hospital is a tertiary level teaching and referral hospital catering more than 450 beds for inpatients and rendering referral health services for over 5 million inhabitants in the North-west Ethiopia.

\section{Sample selection criteria}

During patient selection, a standard definition for post operative surgical site infection was used [16]

\section{Bacteriological procedures}

A standardized pretested questionnaire was used to obtain data from the patients. Pus swabs were aseptically obtained using sterile cotton wool swabs from surgical sites before the wound was cleaned by antiseptic solution. Environmental sampling was also conducted in two different wards and operating rooms. Furthermore, we evaluated bacterial contamination of personnel nasal swabs and some medical equipment too. All surface samples were taken after decontamination. The swab specimens were transported to the Microbiology Laboratory of Gondar Teaching Hospital, within 1-2 hours of collection.

Sample/rinse method was used for sampling in the present study. Cotton tipped sterile swabs that were moistened in sterile brain-heart infusion broth (BHI) (Merck, Germany) were used to take samples from different surfaces. In each sampling, approximately $25 \mathrm{~cm}^{2}$ was covered by moistened swab. The samples were categorized to clinical (patients area) and non-clinical surfaces (common area). The main target of sampling was hand contact surfaces [17].

\section{Culture of specimens}

The specimens were inoculated on nutrient agar, MacConkey agar, mannitol salt agar, blood agar and chocolate agar (Oxoid, Basingstoke, and Hampshire, UK, England). Plates were thereafter incubated at $37^{\circ} \mathrm{C}$ for $24-48$ hours. Primary cultures were sub cultured following the standard procedures [18].

\section{Identification of bacterial pathogens}

Pure cultures on secondary plates were characterized using physical appearances on selective and differential media. Biochemical tests such as catalase, coagulase, oxidase, Voges-Prauskauer, hydrogen sulphide test, urease, methyl red, indole, citrate and sugar utilization tests were done for each pathogen following the standard procedures [18].

\section{Antibiotics used and concentrations}

A total of fifteen antibiotics which represent the most commonly prescribed antibiotics in the study area were used in this study: amoxicillin $(30 \mu \mathrm{g})$, ampicillin $(10 \mu \mathrm{g})$, ceftriaxone $(30 \mu \mathrm{g})$, chloramphenicol $(30 \mu \mathrm{g})$, erythromycin $(15 \mu \mathrm{g})$, gentamicin $(10 \mu \mathrm{g})$, methicillin $(5 \mu \mathrm{g})$, trimethoprim sulphamethoxazole (TMP-SMX) $(25 \mu \mathrm{g})$, vancomycin $(30 \mu \mathrm{g})$, doxycycline $(30 \mu \mathrm{g})$, amikacin $(30 \mu \mathrm{g})$, clindamycin $(2 \mu \mathrm{g})$, ciprofloxacin $(5 \mu \mathrm{g})$, kanamycin $(30 \mu \mathrm{g})$, tetracycline $(30 \mu \mathrm{g})$. The criteria used to select the antimicrobial agents tested were based on their availability and frequent prescriptions for the management of wound infections.

\section{Antibiotic susceptibility testing}

Susceptibility testing was performed by Kirby-Bauer technique [19] according to the criteria of the National Committee for Clinical Laboratory Standards by disc diffusion method [20]. From a pure culture 3-5 pure colonies of bacteria were taken and transferred in to a tube containing $5 \mathrm{ml}$ sterile nutrient broth (Oxoid) and mixed gently until the turbidity of the suspension become adjusted to a McFarland 0.5 standard. Using sterile cotton swab, the bacteria were seeded evenly over the entire surface of Mueller-Hinton agar ( $\mathrm{pH}$ 7.2-7.4) (Oxoid). The plates were left at room temperature to dry for 3-5 minutes and a set of 15 antibiotic discs (Oxoid) with the recommended concentrations were placed on the surface of a Muller-Hinton plate. Finally, the plates were incubated at $37^{\circ} \mathrm{C}$ for 24 hours. Diameters of growth inhibition around the discs were measured and interpreted as sensitive, intermediate or resistant as per the standard protocol [21]. Reference strains E. coli ATCC 25922 and S. aureus ATCC 25923 were tested as controls according to the National Committee for Clinical Laboratory Standards (NCCLS) [20].

\section{Data analysis}

The data were entered and analyzed using SPSS soft ware version 16 package. Simple descriptive statistics were used to present the findings.

\section{Ethical consideration}

Patients were enrolled after obtaining informed consent. The consents of children were obtained through their parents and guardians. Ethical clearance was obtained from the Research and Publication Office of the University of Gondar. Patients with positive isolate were managed following the routine patients' management system of the hospital.

\section{Results}

A total of 1627 surgical procedures were undertaken from surgery and gynaecology and obstetrics wards during the study period and among this a total of 57 (3.5\%) patients developed post operative surgical wound infections. Among these 57 patients, 36 (63.2\%) were females and $21(36.8 \%)$ were males. The ages of the study groups ranged from 7 to 75 years. Forty-three (38.7\%) of bacterial pathogens were identified from study participants below the age of 21 years old. Emergency type of surgery represented 83 (74.8\%) of the bacterial pathogens. Most (64.9\%) of the bacterial pathogens were recovered within 10 days after operation. One hundred and one (91\%) of the bacterial pathogens were isolated from patients who had already a prophylaxis before surgery was undertaken (Table 1).

One hundred eleven bacteria were isolated and among these 70 (63.1\%) and 41 (36.9\%) were from surgical and gynecology \& obstetrics wards, respectively. Gram negative and Gram positive bacteria represented $62(55.9 \%)$ and $49(44.1 \%)$, respectively. The most common isolates was Escherichia coli $(27 / 111,24.3 \%)$ followed by S.aureus (26/111, $23.4 \%)$, coagulase negative Staphylococci (CoNS) $(22 / 111,19.8 \%)$ and Enterobacter spp. (11/111, 9.9\%) (Table 2).

Overall bacterial isolates were seen at the surgical ward 70(63.1\%) were higher than gynaecology and obstetrics wards $41(36.9 \%)\left(\mathrm{X}^{2}=\right.$ 15.2, $\mathrm{P}<0.001)$. The same was true for Enterobacter spp. $10(90.9 \%)$ $(\mathrm{P}=0.05)$ but $S$. aureus $15(57.7 \%)$ was significantly higher in gynaecology and obstetrics ward $\left(\mathrm{X}^{2}=6.28, \mathrm{P}<0.012\right)$ (Table 2$)$. Although higher distribution of S. aureus 21 (80.8\%), CoNS 14(63.6\%), E. coli 17(63.0), and Enterobacter spp. 10 (90.9\%) were isolated from patients who undergo emergency type of surgery, the difference was statistically non- 
Citation: Amare B, Abdurrahman Z, Moges B, Ali J, Muluken L, et al. (2011) Postoperative Surgical Site Bacterial Infections and Drug Susceptibility Patterns at Gondar University Teaching Hospital, Northwest Ethiopia. J Bacteriol Parasitol 2:126. doi:10.4172/2155-9597.1000126

Page 3 of 6

\begin{tabular}{|c|c|c|c|c|}
\hline & \multirow[b]{2}{*}{ Variable } & \multicolumn{2}{|c|}{ Ward } & \multirow{2}{*}{$\begin{array}{l}\text { Total } \\
\text { No (\%) }\end{array}$} \\
\hline & & $\begin{array}{l}\text { Surgical } \\
\text { No (\%) }\end{array}$ & $\begin{array}{c}\text { Gyn and } \\
\text { Obs. No (\%) }\end{array}$ & \\
\hline \multirow{2}{*}{ Sex } & Female & $30(42.3)$ & $41(57.7)$ & $71(100.0)$ \\
\hline & Male & $40(100.0)$ & -- & $40(100.0)$ \\
\hline \multirow{6}{*}{ Age group } & $<10$ & $3(100.0)$ & -- & $3(100.0)$ \\
\hline & $11-20$ & $14(35.0)$ & $26(65.0)$ & $40(100.0)$ \\
\hline & $21-30$ & $19(70.4)$ & $8(29.6)$ & $27(100.0)$ \\
\hline & $31-40$ & $7(53.8)$ & $6(46.2)$ & $13(100.0)$ \\
\hline & $41-50$ & $6(85.7)$ & $1(14.3)$ & $7(100.0)$ \\
\hline & $>50$ & $21(100.0)$ & -- & $21(100.0)$ \\
\hline \multirow{2}{*}{ Case type } & Emergency & $46(55.4)$ & $37(44.6)$ & $83(100.0)$ \\
\hline & Elective & $24(85.7)$ & $4(14.3)$ & $28(100.0)$ \\
\hline \multirow{3}{*}{$\begin{array}{l}\text { Rank of } \\
\text { physician did } \\
\text { the surgery }\end{array}$} & Surgeon & 17 (73.9) & $6(26.1)$ & $23(100.0)$ \\
\hline & Resident & $44(100.0)$ & -- & $44(100.0)$ \\
\hline & General practioner(GP) & $9(20.5)$ & $35(79.5)$ & $44(100.0)$ \\
\hline \multirow{2}{*}{ Prophylaxis } & Yes & $62(61.4)$ & $39(38.6)$ & $101(100.0)$ \\
\hline & No & $8(80.0)$ & $2(20.0)$ & $10(100.0)$ \\
\hline \multirow{4}{*}{$\begin{array}{l}\text { Hospital stay } \\
\text { (in days) }\end{array}$} & $<10$ & $44(61.1)$ & $28(38.9)$ & $72(100.0)$ \\
\hline & $10-20$ & $9(47.4)$ & $10(52.6)$ & $19(100.0)$ \\
\hline & $21-30$ & $8(72.7)$ & $3(27.3)$ & $11(100.0)$ \\
\hline & $31-60$ & $9(100.0)$ & - & $9(100.0)$ \\
\hline
\end{tabular}

Table 1: Bacterial distribution among patient characteristics from post operative surgical site infections at Gondar University Teaching Hospital, 2010.

\begin{tabular}{|l|l|l|l|l|}
\hline \multicolumn{5}{|l|}{ Wards } \\
\hline Bacterial isolate & Surgical N(\%) & Gyn and Obs N (\%) & Total N (\%) & $\mathbf{X}^{2}$ \\
\hline S. aureus§ & $11(42.3)$ & $15(57.7)$ & $26(100.0)$ & 6.28 \\
\hline CoNS* & $11(50.0)$ & $11(50.0)$ & $22(100.0)$ & 2.01 \\
\hline E. coli & $18(66.7)$ & $9(33.3)$ & $27(100.0)$ & 0.2 \\
\hline P. aeruginosa & $2(66.7)$ & $1(33.3)$ & $3(100.0)$ & - \\
\hline K. pneumoniae & $4(66.7)$ & $2(33.3)$ & $6(100.0)$ & - \\
\hline P.mirabilis & $3(75.0)$ & $1(25.0)$ & $4(100.0)$ & - \\
\hline Enterobacter spp. & $10(90.9)$ & $1(9.1)$ & $11(100.0)$ & - \\
\hline S. arizonae & $4(100.0)$ & - & $4(100.0)$ & ND \\
\hline Edwardsiella spp. & - & $1(100.0)$ & $1(100.0)$ & ND \\
\hline M. morganii & $6(100.0)$ & - & $6(100.0)$ & ND \\
\hline $\begin{array}{l}\text { Other gram-positive } \\
\text { aerobes }\end{array}$ & $1(100.0)$ & - & $1(100.0)$ & ND \\
\hline Total § & $70(63.1)$ & $41(36.9)$ & $111(100.0)$ & 15.2 \\
\hline
\end{tabular}

${ }^{*}$ CoNS: Coagulase negative Staphylococci

$\S \mathrm{P}<0.05$

ND: Not determined

Table 2: Bacterial distribution from both surgical and gynecology \& obstetrics wards at Gondar University Teaching Hospital, 2010.

significant (Table 3). However, the over all bacterial isolates distribution showed that majority of were from patients who undergone emergency surgery $83(74.8 \%)\left(\mathrm{X}^{2}=54.5, \mathrm{P}<0.001\right)$ (Table 3$)$.

From all 111 pathogenic bacteria isolated; 44 (39.6\%) were detected from patients operated by residents in the Department of surgery and $35(31.5 \%)$ were from patients operated by general practitioners in the Department of Gynecology and Obstetrics (Table 4).

The susceptibility patterns of bacteria isolated from surgical site infection against 15 antimicrobial agents are presented in Table 5. Clindamycin, doxycycline, erythromycin, methicillin and vancomycin were tested only for Gram positive bacteria. High level of resistance was observed against amoxicillin (95.5\%), ampicillin (89.2\%), TMP-SMX (80.2\%) and chloramphenicol (74.8\%) (Table 5).

Out of 27 isolates of E. coli, (100\%), (96.3\%), (92.6\%), (88.9\%),

\begin{tabular}{|l|l|l|l|l|}
\hline \multirow{2}{*}{ Bacteria isolated } & \multicolumn{5}{|c|}{ Case Type } \\
\cline { 2 - 5 } & Emergency No (\%) & Elective No (\%) & Total No (\%) & $\mathbf{X}^{2}$ \\
\hline S. aureus & $21(80.8)$ & $5(19.2)$ & $26(100.0)$ & 0.65 \\
\hline CoNS & $14(63.6)$ & $8(37.0)$ & $22(100.0)$ & 1.80 \\
\hline E. coli & $17(63.0)$ & $10(37.0)$ & $27(100.0)$ & 2.64 \\
\hline P. aeruginosa & $3(100.0)$ & - & $3(100.0)$ & ND \\
\hline K. pneumoniae & $4(66.7)$ & $2(33.3)$ & $6(100.0)$ & - \\
\hline P. mirabilis & $3(75.0)$ & $1(25.0)$ & $4(100.0)$ & - \\
\hline Enterobacter spp. & $10(90.9)$ & $1(9.2)$ & $11(100.0)$ & - \\
\hline S. arizonae & $4(100.0)$ & - & $4(100.0)$ & ND \\
\hline Edwardsiella spp. & $1(100.0)$ & - & $1(100.0)$ & ND \\
\hline M. morganii & $6(100.0)$ & - & $6(100.0)$ & ND \\
\hline $\begin{array}{l}\text { Other gram-positive } \\
\text { aerobes }\end{array}$ & - & $1(100.0)$ & $1(100.0)$ & ND \\
\hline Total§ & $83(74.8)$ & $28(25.2)$ & $111(100.0)$ & 54.5 \\
\hline
\end{tabular}

$\S \mathrm{P}<0.05$

Table 3: Bacterial distribution based on case type among surgical and gynecology \& obstetrics wards at Gondar University Teaching Hospital, 2010.

\begin{tabular}{|c|c|c|c|c|c|c|}
\hline \multirow{3}{*}{$\begin{array}{l}\text { Bacterial } \\
\text { isolate }\end{array}$} & \multicolumn{5}{|c|}{ Wards } & \multirow{3}{*}{$\begin{array}{l}\text { Total } \\
\text { No. }(\%)\end{array}$} \\
\hline & \multicolumn{3}{|c|}{ Surgical $(N=70)$} & \multicolumn{2}{|c|}{ Gyn and Obs $(N=41)$} & \\
\hline & Surgeon & Resident & GP & Surgeon & GP & \\
\hline S. aureus & $5(19.2)$ & $5(19.2)$ & $1(3.8)$ & $3(11.5)$ & $12(46.2)$ & $26(100.0)$ \\
\hline CoNS & - & $10(45.5)$ & $1(4.5)$ & $3(11.5)$ & $8(36.4)$ & $22(100.0)$ \\
\hline E. coli & $2(7.4)$ & $12(44.4)$ & $4(14.8)$ & - & $9(33.3)$ & $27(100.0)$ \\
\hline$P$. aeruginosa & - & $1(33.3)$ & $1(33.3)$ & - & $1(33.3)$ & $3(100.0)$ \\
\hline K. pneumoniae & $1(16.7)$ & $3(50.0)$ & & - & $2(33.3)$ & $6(100.0)$ \\
\hline P. mirabilis & $1(25.0)$ & $1(25.0)$ & $1(25.0)$ & - & $1(25.0)$ & $4(100.0)$ \\
\hline $\begin{array}{l}\text { Enterobacter } \\
\text { spp. }\end{array}$ & $3(27.3)$ & $6(54.5)$ & $1(9.1)$ & - & $1(9.1)$ & $11(100.0)$ \\
\hline S. arizonae & $2(50.0)$ & $2(50.0)$ & - & - & - & $4(100.0)$ \\
\hline $\begin{array}{l}\text { Edwardsiella } \\
\text { spp. }\end{array}$ & - & - & - & & $1(100.0)$ & $1(100.0)$ \\
\hline M. morganii & $3(50.0)$ & $3(50.0)$ & - & - & - & $6(100.0)$ \\
\hline $\begin{array}{l}\text { Other gram- } \\
\text { positive } \\
\text { aerobes }\end{array}$ & - & $1(100.0)$ & - & - & - & $1(100.0)$ \\
\hline Total & $17(24.2)$ & $44(62.9)$ & $9(12.9)$ & $6(14.6)$ & $35(85.4)$ & 111(100.0) \\
\hline
\end{tabular}

Table 4: Distribution of bacteria from patients operated by physicians with different ranks in surgical and gynecology and obstetrics wards at Gondar University Teaching Hospital, 2010.

(77.8\%), (70.4\%), (70.4\%), (59.2\%), (55.6\%), and (29.6\%) were resistant to amoxicillin, ampicillin, chloramphenicol, TMP-SMX, tetracycline, kanamycin, amikacin, gentamicin, ceftriaxone, and ciprofloxacin, respectively. Among 11 isolates of Enterobacter spp., 11 (100\%), 11 $(90.9 \%)$ and $9(81.8 \%)$ were resistant to amoxicillin, ampicillin and TMP-SMX, respectively but 11 (100\%) of them were sensitive to ciprofloxacin (Table 5).

From 26 isolates of S. aureus, 9 (34.6\%) were methicillin-resistant but $26(100 \%)$ and $23(88.5 \%)$ of them were sensitive to vancomycin and clindamycin, respectively. Among the 22 isolate of CoNS, 17 (77.3\%) were methicillin-resistant and 20 (90.9\%) were resistant for doxycycline and chloramphenicol, while 1 (4.5\%) of them were resistant to vancomycin (Table 5).

Distribution and frequency of bacterial isolates from hospital environment are presented in table 6 . Bacterial pathogens were assessed from 75 environmental sites showing an isolation rate of 41 (54.7\%). Coagulase negative Staphylococcus 41 (41.8\%), S. aureus 19 (19.4\%), Pseudomonas. aeruginosa $16(16.3 \%)$ and E.coli 10 (10.2\%) were the major isolates. Majority of bacteria 60 (61.2\%) were isolated from op- 


\begin{tabular}{|c|c|c|c|c|c|c|c|c|c|c|c|c|c|c|c|}
\hline \multirow{2}{*}{ Organism } & \multicolumn{15}{|c|}{ Antimicrobial agents, N (\%) } \\
\hline & AMP & AML & A & $\mathbf{E}$ & MET & DO & DA & VA & CIP & CRO & $\mathrm{CN}$ & $\mathbf{K}$ & TTC & TMP-SMX & C \\
\hline E. coli & 96.3 & 100 & 70.4 & ND & ND & ND & ND & ND & 29.6 & 55.6 & 59.2 & 70.4 & 77.8 & 88.9 & 92.6 \\
\hline S.aureus & 80.8 & 96.2 & 50.0 & 50 & 34.6 & 53.8 & 11.5 & nil & 42.3 & 50 & 61.5 & 61.5 & 34.6 & 65.4 & 61.5 \\
\hline $\mathrm{CoNs}^{*}$ & 86.3 & 81.8 & 63.6 & 54.5 & 77.3 & 90.9 & 13.6 & 4.5 & 40.9 & 68.2 & 59.1 & 54.5 & 68.2 & 81.8 & 90.9 \\
\hline Enterobacter spp. & 90.9 & 100.0 & 63.6 & $N^{*}$ & ND & ND & ND & ND & nil & 54.6 & 54.6 & 45.5 & 27.3 & 81.8 & 45.5 \\
\hline K. pneumonia & 100.0 & 100.0 & 66.7 & ND & ND & ND & ND & ND & 33.3 & 83.3 & 33.3 & 50 & 50.0 & 83.3 & 66.7 \\
\hline M. morganii & 100.0 & 100.0 & 16.7 & ND & ND & ND & ND & ND & 16.7 & 16.7 & 33.3 & 33.4 & 66.7 & 83.3 & 33.3 \\
\hline P. mirabilis & 75.0 & 100.0 & 50 & ND & ND & ND & ND & ND & nil & 75.0 & 25.0 & 100 & 75.0 & nil & 100.0 \\
\hline S. arizonae & 75.0 & 100.0 & 100 & ND & ND & ND & ND & ND & nil & 50.0 & 50.0 & 25.0 & 50.0 & 50.0 & 50.0 \\
\hline P.aeruginosa & 100.0 & 100.0 & 66.7 & ND & ND & ND & ND & ND & 33.3 & 100 & 66.7 & 100.0 & 100.0 & 100.0 & 100.0 \\
\hline Edwardsiella spp. & 100.0 & 100.0 & 100.0 & ND & ND & ND & ND & ND & nil & nil & 100 & 100.0 & 100.0 & 100.0 & 100.0 \\
\hline Other gram-positive aerobes & 100.0 & 100.0 & 100.0 & 100.0 & 100.0 & 100.0 & nil & nil & 100.0 & 100 & 100.0 & 100.0 & nil & 100.0 & 100.0 \\
\hline Total & 89.2 & 95.5 & 61.3 & 53.0 & 55.0 & 69.4 & 12.0 & 2.0 & 29.7 & 57.7 & 55.9 & 60.4 & 57.7 & 80.2 & 74.8 \\
\hline
\end{tabular}

* CoNs: Coagulase Negative Staphylococci; ND = not done; AMP: Ampicillin; AML: Amoxicillin; A: Amikacin; E: Erythromycin; MET: Methicillin; DO: Doxycycline; DA: Clindamycin; VA: Vancomycin; CIP: Ciprofloxacin; CRO: Ceftriaxone; CN: Gentamicin; K: Kanamycin; TTC: Tetracycline; TMP-SMX: Trimethoprim-sulphamethoxazole; C: Chloramphenicol; nil: all are sensitive.

Table 5: Resistance Patterns (in percentages) of bacteria isolated from surgical site wounds at Gondar University Teaching Hospital, 2010.

erating room from which gram positive bacteria accounts $44(73.3 \%)$ (Table 6). The resistance pattern of bacterial isolates from the environment is indicted in table 7. E. coli was resistant to ampicillin $(90.0 \%)$, amoxicillin $(100.0 \%)$, tetracycline $(70.0 \%)$, TMP-SMX $(70.0 \%)$, and kanamycin (60.0\%). K. pneumonia was resistant to amikacin (80.0\%), gentamicin (80.0\%), chloramphenicol (60.0\%), and ceftriaxone $(60.0 \%)$ (Table 7). Citrobacter spp. and Serriata spp. were resistant to most antimicrobial agents tested. Two (2.0\%) MRSA isolates were obtained from operating room samples which were culture positive.

\section{Discussion}

Successful management of patients with bacterial infection depends on the identification of bacterial pathogens and on the selection of an antibiotic effective against the organism in question. Antibiotics are one of the pillars of modern medical care and play a major role both as the prophylaxis and treatment of infectious diseases. The issue of their availability, selection and proper use are of critical importance to the global community [22].

The result of this study showed that E. coli, S. aureus, CoNS and Enterobacter spp. were highly associated with surgical wound infections. Over all, more bacterial pathogens were more commonly isolated from surgery ward. However, S. aureus was a major pathogen from patients in Gynecology and Obstetrics wards and most commonly isolated bacteria from patients who undergone emergency type of surgery which may be due to surface contamination by this bacterium on the skin and environment causing nosocomial infections. E. coli was most commonly isolated from patients who undergone elective type of surgery which can be due to contamination of wounds with patient's endogenous flora since E. coli and Coliforms is normal flora of gastro-intestinal tract [23]. According to CDC [24], S. aureus, CoNS and E. coli was the most prevalent organism associated with surgical wound infections [24]. The current findings showed $55.9 \%$ and $44.1 \%$ of Gram negative and Gram positive bacteria, respectively which is comparable with a study done by Kollef [25] on surgical nosocomial infections which reported $50.3 \%$ Gram-negative bacteria followed by Gram-positive bacteria 31.1\%.

From the total isolated bacteria, 91\% were isolated from patients who received antibiotic prophylaxis before surgery which is in agreement with similar study reported from Addis Ababa [22,26,27]. The present study showed relatively frequent isolation among patients who received antibiotic prophylaxis and the most commonly prescribed drug for prophylaxis was ampicillin alone or in combination with other antibiotics such as gentamicin and chloramphenicol. This shows some antibiotics alone or in combination, requires periodic evaluation and the establishment of antibiotics policy for prophylaxis and treatment guidelines in the Ethiopian setting.

The prevalence of bacterial contamination among all wards that was done in line to isolation of pathogens from patients has not been determined accurately yet and the current study was the first one in our hospital. The fact that most Gram-positive bacteria, such as MRSA contaminate the inanimate environment has been well established in colonized or infected patients, personnel in the hospitals and the major mechanism is done via the unwashed hands of health care workers [29]. Presence of bacteria was different from ward to ward based on activities. For example $S$. aureus and CoNS were the predominant isolate in operating rooms; whereas $P$. aeruginosa was the main isolate in surgical ward and gynecology and obstetrics wards. Most of isolates were from operating rooms, and many studies suggested that excellent surgical technique is widely believed to reduce the risk of surgical site infections [30-33].

The susceptibility testing of S. aureus showed 9(34.6\%) were resistant to methicillin which is slightly lower than (38.56\%) from Delhi [33] and higher than (21.7\%) from Chennai [34]. All isolates of S. aureus were sensitive to vancomycin which seems to be the only antimicrobial agent which shows $100 \%$ sensitivity but $88.5 \%$ were sensitive to clindamycin. Vancomycin remains the first choice of treatment for MRSA

\begin{tabular}{|c|c|c|c|c|}
\hline \multirow[b]{2}{*}{ Bacterial isolate } & \multicolumn{3}{|c|}{ Wards } & \multirow[b]{2}{*}{ Total No. (\%) } \\
\hline & $\begin{array}{l}\text { Surgical ward } \\
\text { No. (\%) }\end{array}$ & $\begin{array}{l}\text { Operating } \\
\text { room No. (\%) }\end{array}$ & $\begin{array}{l}\text { Gyn and Obs } \\
\text { No. }(\%)\end{array}$ & \\
\hline E. coli & - & $8(80.0)$ & 2(20.0) & $10(100.0)$ \\
\hline Klebsiella spp. & - & $3(60.0)$ & $2(40.0)$ & $5(100.0)$ \\
\hline Citrobacter spp. & - & $1(100.0)$ & - & $1(100.0)$ \\
\hline P.aeruginosa & $12(75.0)$ & $1(6.3)$ & $3(18.8)$ & $16(100.0)$ \\
\hline Serraitia spp. & $1(50.0)$ & - & $1(50.0)$ & $2(100.0)$ \\
\hline S. aureus & $5(26.3)$ & 14(73.7) & & $19(100.0)$ \\
\hline CoNS & $10(24.4)$ & $30(73.2)$ & $1(2.4)$ & $41(100.0)$ \\
\hline Proteus spp. & $1(25.0)$ & $3(75.0)$ & - & $4(100.0)$ \\
\hline Total & $29(29.6)$ & $60(61.2)$ & $9(9.2)$ & $98(100.0)$ \\
\hline
\end{tabular}

Table 6: Frequency and type of bacterial isolates from hospital environment at Gondar University Teaching hospital. 


\begin{tabular}{|c|c|c|c|c|c|c|c|c|}
\hline \multirow{2}{*}{$\begin{array}{l}\text { Antimicrobial } \\
\text { agents }\end{array}$} & \multicolumn{8}{|c|}{ Organism } \\
\hline & E. coli & S.aureus & CoNS* & K. pneumonia & P. mirabilis & $P$. aeruginosa & Citrobacter spp. & Serratia spp. \\
\hline Ampicillin & 90.0 & 21.1 & 36.6 & 100.0 & 100.0 & 81.3 & 100.0 & 100.0 \\
\hline Amoxicillin & 100.0 & 100.0 & 97.6 & 100.0 & 100.0 & 81.3 & 100.0 & 100.0 \\
\hline Amikacin & 50.0 & 42.1 & 51.2 & 80.0 & 25.0 & 50.0 & None & 50.0 \\
\hline Erythromycin & ND & 15.8 & 19.5 & ND & ND & ND & ND & ND \\
\hline Methicillin & ND & 10.5 & 41.5 & ND & ND & ND & ND & ND \\
\hline Doxycycline & ND & 31.6 & 34.1 & ND & ND & ND & ND & ND \\
\hline Clindamycin & ND & 31.6 & 14.6 & ND & ND & ND & ND & ND \\
\hline Vancomycin & ND & None & 4.9 & ND & ND & ND & ND & ND \\
\hline Ciprofloxacin & 40.0 & 5.3 & 19.5 & 20.0 & None & 12.5 & 100.0 & 50.0 \\
\hline Ceftriaxone & 30.0 & 5.3 & 22.0 & 60.0 & 50.0 & 75.0 & 100.0 & 100.0 \\
\hline Gentamicin & 40.0 & 26.3 & 26.8 & 80.0 & None & 25.0 & 100.0 & 100.0 \\
\hline Kanamycin & 60.0 & 47.4 & 53.7 & 20.0 & 75.0 & 56.3 & 100.0 & None \\
\hline Tetracycline & 70.0 & 57.9 & 39.0 & 20.0 & 25.0 & 37.5 & 100.0 & 100.0 \\
\hline SXT & 70.0 & 31.6 & 43.9 & 60.0 & 25.0 & 37.5 & 100.0 & None \\
\hline Chloramphenicol & 50.0 & 26.3 & 58.5 & 60.0 & 75.0 & 43.8 & 100.0 & 100.0 \\
\hline
\end{tabular}

Table 7: Resistance pattern (in percentage) of bacterial isolates from nasal swab of personnel and hospital environment at Gondar University Teaching Hospital.

and to preserve its value, vancomycin use should be limited to those cases where there are clearly needed. Methicillin resistant CoNS have become the predominant pathogen and increasing dramatically in hospitalized patients $[35,36]$. According to the current study, methicillin resistant CoNS were $77.3 \%$ which is in line with the study that reported $72.5 \%$ resistant strains [37]. The present study also showed a single isolate of CoNS resistant to vancomycin which is less from the isolates found India [37]. The emergence of vancomycin resistance in CoNS in our teaching hospital may pose therapeutic problems, and therefore the empirical antibiotic treatment of suspected infections caused by CoNS should be prescribed according to antimicrobial susceptibility testing.

The susceptibility testing of the gram-negative organisms; E. coli, $P$. aeruginosa and $P$. mirabilis showed that higher resistant to amoxycillin, ampicillin and ceftriaxone ( $\beta$-lactam antibiotics). This high resistance of organisms to $\beta$-lactam is not surprising, as these antibiotics are the most commonly used antibiotics and resistant pattern were reported from many studies $[14,22,28,36,38]$ in Northwest Ethiopia. Similarly, a study [39] in Europe reported the high resistance of E. coli and P. aeruginosa isolated from surgical wounds.

Majority of gram negative bacteria showed very high resistant to chloramphenicol, tetracycline and TMP-SMX. The high rate of bacterial resistance against chloramphenicol and TMP-SMX is likely due to indiscriminate use of antibiotics both within hospital and outside as it was described two decade ago in the study area [40].

P. aeruginosa were resistant to kanamycin (100\%) and gentamycin (100\%), while $33.3 \%$ were resistant to amikacin. This result is consistent with the data obtained by Clark in USA [37]. The isolation of aminoglycosides resistant $P$. aeruginosa might be plasmid mediated type of resistance leading to membrane impermeability. Regarding to E. coli isolate, more than $70.4 \%$ were resistant to kanamycin and amikacin while $59.2 \%$ were resistant to gentamycin. As many of the isolates were susceptible to gentamycin, the continued use of the drug in surgical conditions is thus indicated.

From the quinolones, ciprofloxacin was highly active against all gram-negative organisms examined. From this investigation, ciprofloxacin stands out to be the most effective antibiotic against pathogens associated with surgical wound infections. However, the level of resistance to ciprofloxacin is increasing from zero in the year 2000 [41] and $16.0 \%$ in the year of 2004 [28] to $27 \%$ in the present study
(2010). Thus the frequency of single as well as multiple drug resistance was alarmingly high. This might be a reflection of inappropriate use of antimicrobials, lack of diagnostic laboratory services or unavailability of guideline regarding the selection of drugs that enforce to empirical treatment options.

The higher counts of bacteria obtained from the patients in the wards and from the hospital environment and are of great concern, highlighting the quality of wards and operating rooms, and the need for the attention of the hospital authorities to take necessary preventive measures to maintain a sound and healthy atmosphere for the patients, as well as the hospital personnel. There is a need to reinforce rational antimicrobial use to limit emergence and spread of resistant and /or continuing surveillance of bacterial antimicrobial sensitivity tests at local level to guide empirical drug choice. The practice of aseptic technique during and after surgery rather than overreliance on antibiotics is necessary to reduce emergence and spread of resistant pathogens. Future studies should be extended to include cultures under anaerobic conditions to establish presence of other organisms that require such environment for growth. It is also recommended that gentamicin, ciprofloxacin, vancomycin and clindamycin be used in preference to ampicillin and amoxycillin for treatment of post operative surgical site infections. In this study, anaerobic bacterial, fungal and viral agents were not investigated due to limited laboratory facilities and expertise.

\section{Acknowledgments}

This research was funded by a grant from University of Gondar Research and Publication Office.

\section{References}

1. Patherick ES, Dalton JE (2006) Methods for Identifying surgical wound infections after discharging from Hospital: a systematic review. BMC Infect Dis 6 : 170-178.

2. Skarzynska J, Cienciala A, Madry R, Barucha P, Kwasniak M, et al. (2000) Hospital infection in general surgery wards. Przegl Epidemiol 54: 299-304.

3. Kirkland KB, Briggs JP, Trivette SL, Wilkinson WE, Sexton DJ (1999) The impact of surgical-site infections in the 1990s: attributable mortality, excess length of hospitalization, and extra costs. Infect Control Hosp Epidemiol 20: 725-730.

4. Mangram AJ, Horan TC, Pearson ML, Silver LC, Jarvis WR (1999) Guideline for prevention of surgical site infection, 1999. Hospital Infection Control Practices Advisory Committee. Infect Control Hosp Epidemiol 20: 250-278.

5. Rahman $\mathrm{MH}$, Anson J (2004) Peri-operative anti-bacterial prophylaxis. Pharmaceutical Journal 272: 743-745.

6. Farina C, Goglio A, Conedera G, Minelli F, and Caprioli A (1996) Antimicro- 
Citation: Amare B, Abdurrahman Z, Moges B, Ali J, Muluken L, et al. (2011) Postoperative Surgical Site Bacterial Infections and Drug Susceptibility Patterns at Gondar University Teaching Hospital, Northwest Ethiopia. J Bacteriol Parasitol 2:126. doi:10.4172/2155-9597.1000126

bial susceptibility of Escherichia coli 0157 and other enterohaemorrhagic Escherichia coli isolated in Italy. Eur J Clin Microbiol Infect Dis 15: 351-353.

7. Nicholas RL (2001) Preventing surgical site infections; a surgeon's perspective. Emerg Infect Dis 7: 220-224

8. Howard RJ, Lee JT JR (1995) Surgical wound infections: epidemiology, surveillance, and clinical management. Allyn \& Bacon. East Norwalk, CT.

9. Thomas KH (1981) Surgical site infections, an overview. American Journal of Medicine 70: 712- 718

10. Anguzu JR, Olila (2007) Drug sensitivity patterns of bacterial isolates from septic post-operative wounds in a regional referral hospital in Uganda. Afr Health Sci 7: 148-154.

11. Low DE, Willey BM, Grey AJ (1995) Multiple antibiotic resistant Enterococci: a treat to surgical patients. Am J Surg 169: 85-115.

12. Miles AA, Williams REO, Clayton-Cooper B (1944) The carriage of $S$. aureus in man and its relation to wound infection. J Pathol Bacteriol 56: 513-524.

13. Okeke IN, Lamikanra A, Edelman R (1999) Socioeconomic and behavioura factors leading to acquired bacterial resistance to antibiotics in developing countries. Emerg Infect Dis 5: 18-27.

14. Kotisso B, Aseffa A (1998) Surgical wound infection in a teaching hospital in Ethiopia. East Afr Med J 75: 402-405.

15. Aseffa A, Gedlu E, Asmelash T (1997) Antibiotic resistance of prevalent Salmonella and Shigella strains in northwest Ethiopia. East African medical journal 74: $708-713$

16. Horan TC, Gaynes RP, Martone WJ, Jarvis WR, Emori TG (1992) CDC definitions of nosocomial surgical site infections (1992) A modification of CDC definitions of surgical wound infections. Infect Control Hosp Epidemiol 13: 606-668.

17. Microbiological Methods Committee (2010) Terms of Reference. Canada.

18. Cheesbrough M (2001) District laboratory practice in tropical countries. University Press, Cambridge, UK

19. Bauer A, Kirby W, Sherirs J, Turck M (1996): Antibiotic susceptibility testing by standard Single disk method. Am J Clin Pathol 45: 493-496.

20. National Committee for Clinical Laboratory on Performance Standards for Antimicrobial Disk Susceptibility Tests (2002) Report Wayne

21. World Health Organization on Basic Laboratory procedures in Clinical Bacteriology (1991) Annual report, Geneva

22. Abula T, Kedir M (2004) The pattern of antibiotic usage in surgical in-patient of a teaching hospital, northwest Ethiopia. Ethiop J Healt Dev 18: 35-38.

23. Brown AD (1990) Bacteriology of wound infections in surgical ward of teaching hospitals. West Afr J Med 9: 4285-4290.

24. CDC NNIS System(1996) National Nosocomial Infections Surveillance (NNIS) Semiannual Report from October 1986-April 1996. Am J Infect Control 24: 380388

25. Kollef MH, Sharpless L, Vlasnik J, Pasque C, Murphy D, et al. ( 1997) The impact of nosocomial infections on patient outcomes following cardiac surgery. Chest 112: 666-675.

26. Gedebou M, Habte-Gabr E, Göran K, Yoseph S(1988) Hospital-acquired infections among obstetric and gynaecological patients at Tikur Anbessa Hospital, Addis Ababa. J Hosp Infect 11: 50-59.

27. Gedebou M, Kronvall G, Habte-Gabr E, Ringertz S(1987) The bacteriology of nosocomial infections at Tikur Anbessa Teaching Hospital, Addis Ababa. Acta Pathol Microbiol Immunol Scand B 95: 331-336

28. Mulu A, Moges F, Tessema B, Kassu A (2006) Pattern and Multiple Drug Resistance of Bacterial Pathogens Isolated from Wound Infection at University of Gondar Teaching Hospital, Northwest Ethiopia. Ethiop Med J 32: 125-131

29. Mohanty S, Arti K, Dhawan B, Das BK (2004) Bacteriological and antimicrobia susceptibility of soft tissue infection from northern India. Indian J Med Sci 58: 10-15

30. Kownhar H, Shankar EM, Vignesh R, Sekar R, Velu V, et al. (2008) High isolation rate of Staphylococcus aureus from surgical site infection in an Indian hospital. J Antimicrob Chemother 6:758-760

31. Sohn A, Garrett D, Sinkowitz-Cochran R (2001) Prevalence of nosocomial infections in neonatal intensive care unit patients: results from the first national point-prevalence survey. J Pediatr 136: 821- 827
32. Koksal F, Yasar H, Samasti M (2007) Antibiotics resistant patterns of coagulase-negative staphylococcus strains from blood cultures of septicemic in Turkey. Microbiol Res 16:31-34

33. Habeeb K, Mohammad A (2010) Prevalence and antibiotic susceptibility pattern of methicillin-resistant and coagulase-negative Staphylococci in a tertiary care hospital in India. International Journal of Medicine and Medical Sciences 2: $116-120$

34. Uma C, Bharti A, Madhu S (2008) The Prevalence of Methicillin-Resistant Coagulase-Negative Staphylococcus in a Tertiary Care Hospital in North India. J Infect Dis Antimicrob Agents 25: 13-17

35. Fluit AC, Jones ME, Schmitz FJ, Acar J, Gupta R, et al. (2000) Antimicrobia Susceptibility and Frequency of occurrence of clinical blood isolates in Europe from the SENTRY Antimicrobial Surveillance program 1997 and 1998. Clin Infect Dis 32: 454-460.

36. Aseffa A, Desta Z, Taddesse I (1995) Prescribing patterns of antibacterial drugs in a teaching hospital in Gondar, Ethiopia. East Afr Med J 72: 56-59

37. Clark RB, Sanders C, Pakiz CB, Marcia K (1998) Aminoglycosides resistance among Pseudomonas aeruginosa isolates with an unusual disk diffusion antibiogram. Antimicrob Agents Chemother 32: 689-692.

38. Moges F, Genetu A, Mengistu G(2002) Antibiotics sensitivity of common Bacterial Pathogens in UTI at Gondar Hospital, Ethiopia. East Afr Med J 79: 140-142

39. Hota B (2004) Contamination, disinfection, and cross-colonization are hospital surface reservoirs for nosocomial infection? Clin Infect Dis 39: 1182-1189

40. Dellinger EP (1997) Surgical infections and choice of antibiotics. (15thedn), W.B.Saunders Co. DC. Philadelphia.

41. Mayhall CG (1993) Surgical infections including burns. (2ndedn), Edited by Wenzel RP. Williams \& Wilkins, Baltimore.

42. Zacharias A, Habib RH (1996) Delayed primary closure of deep sternal wound infections. Tex Heart Inst J 23: 211-216 